\section{The effect of wood vinegar on nutritional value and}

\section{fermentation of grass silage}

\section{ABSTRACT}

This study was carried out to determine the effects of wood vinegar (WV) used in different concentrations on nutrient composition, fermentation progress and microflora of grass silage. The study material was composed one control $(0 \% \mathrm{WV})$ and three experimental groups consisting of $0.5 \%, 1 \%$ and $2 \% \mathrm{WV}$, respectively. Each group was made with four replicates. WV was applied to the grass prepared from the natural meadow of Kafkas University and prepared in the laboratory scale conditions by spray method at given rates $(0.5 \%, 1 \%$ and $2 \%)$. The samples were ensiled in $1.0 \mathrm{~L}$ anaerobic jars. $\mathrm{pH}$, dry matter, crude protein, crude fat, crude ash, acid detergent fiber and neutral detergent fiber analyses were performed on the samples opened on the $60^{\text {th }}$ day of fermentation. Also, microbiological analyses were performed for lactic acid bacteria, yeast, and mold by the plate count method. As a result of silage trials carried out under laboratory-scale conditions, WV did not affect nutritional values $(\mathrm{P}>0.05)$. The highest $\mathrm{pH}$ among the treatment groups was observed in the $2 \% \mathrm{WV}$ added group $(\mathrm{P}<0.05)$. While the number of lactic acid bacteria in the WV groups $(0.5$ and $1 \%)$ did not change when compared to the control group $(\mathrm{P}>0.05)$, the highest $(2 \%)$ concentration of WV showed significant antimicrobial activity on lactic acid bacteria $(\mathrm{P}<0.05)$. Also, it has been determined that $\mathrm{WV}$ may reduce yeast and mold growth compared to the control group $(\mathrm{P}<0.05)$.

Keywords: Fermentation, grass, microbiology, nutritional value, silage, wood vinegar

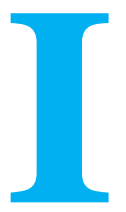

\section{NTRODUCTION}

Charcoal is a carbonization product obtained by burning stacked wood covered in the soil in a limited air environment. During the production of charcoal, a dense smoke liquid consisting of a mixture of liquid organic chemicals and water emerges, which is called wood vinegar (WV) (Norgate et al., 2012). The production of WV, rich in CO, $\mathrm{CO}_{2}, \mathrm{CH}_{4}, \mathrm{~N}_{2}, \mathrm{H}_{2}$ gases, is called pyrolysis (carbonization). There are many organic acids such as acetic acid, formic acid, methanol, phenol and ketone in the structure of wood vinegar obtained by pyrolysis (Chen et al., 2015). Thanks to organic acids in the structure of WV, it has been used as a pesticide since ancient times (Tiilikkala et al., 2010). WV is also rich in phenol and furfural derivatives (Zellagui et al., 2016). Although academic researches about WV started in Japan in the middle of the $20^{\text {th }}$ century, its use reaches the $21^{\text {st }}$ century. Today, it is used as an eco-friendly product in organic agriculture in countries such as Japan, Korea and Taiwan (Namli et al., 2014). It is reported that WV accelerates enzymatic reactions as well as antibacterial and antifungal effects, and the elements in its structure work like enzymes (Rakmai, 2009).

\section{How to cite this article}

ÖImez, M., Büyük, F., Şahin, T., Büyük, E. (2020). The effect of wood vinegar on nutritional value and fermentation of grass silage. Journal of Advances in VetBio Science and Techniques, 5(3), 90-95. https://doi.org/10.31797/vetbio.753680
Research Article

Mükremin ÖLMEZ ${ }^{\text {la }}$ Fatih BÜYÜK ${ }^{2 b}$ Tarkan ŞAHIIN ${ }^{10}$ Eray BÜYÜK ${ }^{2 \mathrm{~d}}$

${ }^{1}$ Department of Animal Nutrition and Nutritional Diseases, Faculty of Veterinary Medicine, Kafkas University, 36100 Kars, Turkey

${ }^{2}$ Department of Microbiology, Faculty of Veterinary Medicine University of Kafkas, 36100, Kars, Turkey

ORCID-

${ }^{\mathrm{a}}$ 0000-0002-5003-3383

${ }^{\mathrm{b}} 0000-0003-3278-4834$

${ }^{\mathrm{c}}$ 0000-0003-0155-2707

d 0000-0003-2071-8901

Correspondence

Mükremin ÖLMEZ

mukremin.olmez@hotmail.com

Article info

Submission: 16-06-2020

Accepted: 09-09-2020

Online First: 28-10-2020

e-ISSN: 2548-1150

doi prefix: $10.31797 /$ vetbio

- http://dergipark.org.tr/vetbio

This work is licensed under a Creative Commons Attribution 4.0 International License (c) (i) 
WV is used in agricultural production to improve the quality of plants and soil, to counteract diseases and pests, to supply the nutrients that the plants need, and to accelerate plant growth (Rakmai, 2009). It has been stated that WV is not toxic to human and animal health. It has been stated that organic acids such as formic acid, which is reported to be in the structure of $\mathrm{WV}$, affects rumen fermentation, increases dry matter (DM) consumption, and yields performance of ruminants (Lehmann \& Joseph, 2009). It has been reported that activated charcoal and WV are used to absorb toxic substances and prevent various diseases (Garillo et al., 1995; Villalba et al., 2002).

This study aims to evaluate the efficiency of wood vinegar used in silage fermentation on nutritional value and microflora of silage. Thus, it will be possible to investigate the ways of using WV added to silage in forage crop cultivation and animal feeding.

\section{MATERIALS and METHODS}

\section{Silage procedure}

This study focused on the grass harvested from the natural meadow of Kafkas University (40³4'37.4"N 4302'54.5"E) in July 2019. For the silage forming plants to have a high dry matter, the shaping period was adjusted to coincide with the end of flowering. After the obtained the grass was exposed to laboratory conditions and withered in the absence of direct sunlight, they were manually chopped into pieces of $2.5-3 \mathrm{~cm}$ in length. The grass laid on a flat surface was divided into four groups to apply different concentrations of WV. It was diluted ten times with distilled water and applied homogeneously on the grass groups by a spray method at the rates of $0 \%, 0.5 \%, 1 \%$ and $2 \%$, respectively. The grass was ensiled in $1 \mathrm{~L}$ anaerobic jars (Weck, Wher-Oftlingen, Germany) and covered with suitable lids. Four samples were prepared for each additive group. The bottled silages were kept in a drying oven $\left(25 \pm 1{ }^{\circ} \mathrm{C}\right)$ for 60 days, and then opened and prepared for analysis. WV (pH: 2.9) obtained during the production of charcoal from the nutshell in Zonguldak Province of Turkey was used in the research.

\section{Analysis of nutritional values of silage}

Particle sizes of the samples were brought to the length and to be used for analysis. The dry matter (DM), crude protein $(\mathrm{CP})$, crude fat $(\mathrm{CF})$ and crude ash (CA) analysis were carried out according to the Weende analysis system (Kitcherside et al., 2000). The acid detergent fiber (ADF) and the neutral detergent fiber (NDF) analysis of the samples were carried out according to the Van Soest method (Goering \& Van Soest, 1970).

\section{Measurement of pH}

In order to determine the $\mathrm{pH}, 25 \mathrm{~g}$ silage samples and $100 \mathrm{ml}$ distilled water were mixed in a laboratory blender (Waring, USA) for 10 minutes. $\mathrm{pH}$ was then measured by $\mathrm{pH}$ meter (Hanna Instruments, USA) according to the method specified by Chen (1994).

\section{Microbiological procedure}

Counting of lactic acid bacteria and fungal agents in the silage samples were carried out by the plate count method. For this purpose, $10 \mathrm{~g}$ silage sample was diluted with $90 \mathrm{ml}$ sterile distilled water and incubated in a shaker incubator at $120 \mathrm{rpm}$ for 2 hours. One $\mathrm{ml}$ homogenate was harvested and tenfold subdilutions $\left(10^{-1}\right.$ to $\left.10^{-6}\right)$ were prepared with sterile distilled water. After diluting, $100 \mu \mathrm{l}$ of each dilution was plated on suitable media in duplicate and spread with an L-shape spreader. The inoculated media were incubated under agent-specific conditions. For this purpose, the Man Rogosa Sharpe (MRS) agar (MRS Agar, Millipore) plates inoculated for the analysis of lactic acid bacteria were incubated at $30{ }^{\circ} \mathrm{C}$ for

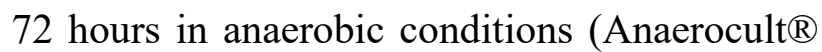
A, Millipore). For the analysis of fungal agents 
(yeast and mold), the samples were plated on Malt Extract Agar (Millipore) and incubated at $25^{\circ} \mathrm{C}$ under aerobic conditions for five days. After the incubation period, the visible colonies on the media were counted. Microorganism density was calculated as a colony-forming unit (CFU) in one gram silage and presented logarithmically (Lee et al., 2019; Skaar \& Stenwig, 1996).

\section{Data management and analysis}

A structured data handling format was prepared, and every vital information (variable) associated with the objective of the investigation was adequately gathered and recorded. After collection, data were inserted in the Microsoft Excel spreadsheet, and percentages of various surgical affections in different Upazilas were calculated. The prevalence of surgical attachments was estimated as the specific cases of surgical affections divided by the total number of infected animals $\times 100$.

\section{RESULTS}

The nutrient analysis results of the silage groups were presented in Table 1. It was determined that the addition of $\mathrm{WV}$ in three different concentrations did not affect the DM, CP, CF, $\mathrm{CA}, \mathrm{ADF}$ and NDF values of the silage $(\mathrm{P}>0.05)$.

Table 1. Nutrient values of grass silage (\%) $($ Mean \pm SEM)

\begin{tabular}{|lcccccc|}
\hline & DM & CP & CF & CA & ADF & NDF \\
\hline Control & $45.69 \pm 3.01$ & $10.94 \pm 0.55$ & $1.51 \pm 0.11$ & $8.74 \pm 0.22$ & $37.05 \pm 1.97$ & $61.43 \pm 1.29$ \\
\hline $\mathbf{0 . 5 \%}$ WV & $44.66 \pm 0.32$ & $11.93 \pm 0.20$ & $1.26 \pm 0.24$ & $8.29 \pm 0.19$ & $36.52 \pm 1.08$ & $58.88 \pm 1.39$ \\
\hline $\mathbf{1 \%}$ WV & $49.05 \pm 0.62$ & $11.58 \pm 0.34$ & $1.09 \pm 0.10$ & $8.50 \pm 0.20$ & $37.11 \pm 0.89$ & $61.66 \pm 1.41$ \\
\hline $\mathbf{2 \%}$ WV & $45.76 \pm 0.62$ & $10.77 \pm 0.31$ & $1.32 \pm 0.16$ & $8.14 \pm 0.44$ & $38.07 \pm 0.99$ & $59.50 \pm 1.92$ \\
\hline $\mathbf{P}$ & 0.272 & 0.154 & 0.359 & 0.489 & 0.865 & 0.504 \\
\hline
\end{tabular}

DM: Dry matter, CP: Crude protein, CF: Crude fat, CA: Crude ash, ADF: Acid detergent fiber,

NDF: Neutral detergent fiber, WV: Wood vinegar, SEM: Standard error mean

Table 2. Grass silage microbiology ( $\log \mathrm{CFU} \mathrm{g}^{-1}$ silage) and $\mathrm{pH}$ values (Mean $\left.\pm \mathrm{SEM}\right)$

\begin{tabular}{|lcccc|}
\hline Control & LAB & Yeast & Mold & pH \\
\hline $\mathbf{0 . 5 \%}$ WV & $5.23 \pm 0.24^{\mathrm{a}}$ & $5.74 \pm 0.15^{\mathrm{a}}$ & $4.65 \pm 0.00^{\mathrm{a}}$ & $5.26 \pm 0.01^{\mathrm{b}}$ \\
\hline $\mathbf{1 \%} \mathbf{W V}$ & $4.70 \pm 0.17^{\mathrm{a}}$ & $5.51 \pm 0.18^{\mathrm{ab}}$ & $4.36 \pm 0.00^{\mathrm{a}}$ & $5.25 \pm 0.00^{\mathrm{b}}$ \\
\hline $\mathbf{2 \%} \mathbf{W V}$ & $4.65 \pm 0.31^{\mathrm{a}}$ & $5.27 \pm 0.24^{\mathrm{ab}}$ & $0.95 \pm 0.00^{\mathrm{b}}$ & $5.25 \pm 0.00^{\mathrm{b}}$ \\
\hline $\mathbf{P}$ & $3.80 \pm 0.16^{\mathrm{b}}$ & $4.85 \pm 0.40^{\mathrm{b}}$ & $0.95 \pm 0.00^{\mathrm{b}}$ & $5.27 \pm 0.00^{\mathrm{a}}$ \\
\hline
\end{tabular}

The results of the microbiological analysis of the silage groups after 60 days of ensiling were presented in Table 2. It was determined that the $\mathrm{pH}$ value was higher in the WV group with the highest $(2 \%)$ concentration when compared to the other groups $(\mathrm{P}<0.05)$. It was observed that the other concentrations of WV $(0.5 \%$ and $1 \%)$ did not have a reducing effect on $\mathrm{pH}$ when compared to the control group.

In this study, antimicrobial activity on silage microflora came to the fore, rather than the acceleration of fermentation in parallel with the increasing concentration of $\mathrm{WV}$. Thus, as the number of lactic acid bacteria in the group treated with $2 \% \mathrm{WV}$ has significantly decreased 
when compared to the control and the other groups $(0.5$ and $1 \%)$, the $\mathrm{pH}$ was influenced $(\mathrm{P}<0.05)$. The presence of yeast and mold were decreased by the supplemented of WV when compared with the control $(\mathrm{P}<0.05)$. The highest (5.74 $\log \mathrm{CFU} \mathrm{g}{ }^{-1}$ ) yeast was counted in the control group whereas the lowest was detected in the group with $2 \% \mathrm{WV}$. The number of molds was lesser than the other groups and equal $\left(0.95 \log \mathrm{CFU} \mathrm{g}{ }^{-1}\right)$ to the groups with $1 \%$ and $2 \% \mathrm{WV}$.

\section{DISCUSSION}

According to the results of the study, the addition of WV did not affect the nutrient content of the silage. Similarly, it has been reported that the addition of organic acid and bacterial inoculants to the silages prepared with a mixture of grass, legume and hays does not affect the nutrient contents (DM, CP, CF, ADF and NDF) (Driehuis et al., 2001; Gül \& Coşkuntuna, 2016; Jatkauskas \& Vrotniakiene, 2011; Jatkauskas et al., 2013; Steen et al., 1989). Jalč et al. (2009) found that there was no significant change in DM, CF and ADF values in grass silage to which they added bacterial inoculants. Moreover, there was no significant change in $\mathrm{CP}, \mathrm{CA}$ and NDF values.

It was observed that WV did not have a positive effect on silage $\mathrm{pH}$, and even used at the highest concentration, the $\mathrm{pH}$ increased in direct proportion with the decreased number of lactic acid bacteria. In general, silage $\mathrm{pH}$ is thought to be high due to the presence of legume plants. In a study where the effectiveness of biochar in WV on silage was investigated, the increase in biochar level was reported to increase $\mathrm{pH}$, similar to the current study (Pereira et al., 2014). Additionally, there are studies reporting that silage $\mathrm{pH}$ did not effect with the addition of different inoculants (Winters et al., 2001; Zhao et al., 2018). There are also studies that differ and have a lowering effect on silage $\mathrm{pH}$ compared to the control group (Gül \& Coşkuntuna, 2016; Jalč et al.,
2009; Jatkauskas \& Vrotniakiene, 2011; Ke et al., 2017)

Lactic acid bacteria are biological additives that increase the production of organic acids such as lactic acid and acetic acid, which accelerate the silage fermentation and prevent the rapid microbial degradation of silage by causing a rapid $\mathrm{pH}$ drop.

That is, lactic acid bacteria capable of living at low $\mathrm{pH}$ are the only desirable microorganisms of an ideal silage microflora. Yeast and molds are undesirable microorganisms that prevent lactic acid fermentation in silage and that accelerate the microbial degradation of silage by increasing $\mathrm{pH}$ as the result of lactic acid destruction. Also, filamentous fungi (mold) have adverse effects on animal health as well as reduce the feed value and flavour of silage (Elferink et al., 2000). In this study, it was determined that the antimicrobial and antifungal effectiveness were prominent in parallel with the increased concentrations of $\mathrm{WV}$, which is thought to contribute positively to the maturation time of silage by accelerating the fermentation of organic matter in silage production. Thus, due to its high acidity and rich ethanol and phenol contents, the antibacterial and antifungal activities of WV with various concentrations have been identified many times (Koç et al., 2019; Koç et al., 2018; Rui et al., 2014). The number of lactic acid bacteria in the group treated with $2 \% \mathrm{WV}$ decreased significantly $(\mathrm{P}<0.05)$ when compared to the control and the other treatment groups. It is not thought that the minimal $\mathrm{pH}$ increase has a positive effect on this decrease in the number of lactic acid bacteria with wide $\mathrm{pH}$ tolerance, especially in the group where $2 \% \mathrm{WV}$ added. Another reason for the low amount of lactic acid bacteria is the possibility that the silages may consist of bacterial strains with weak acid-producing and osmotolerance properties. Indeed, in this study, the subspecies of lactic acid bacteria were not detected. The microflora consisting of bacterial 
communities with different growth characteristics and different sugar metabolisms may adversely affect silage fermentation, as well (McDonald et al., 1991; Woolford, 1984). It should also be noted that the crop properties of the products used in silage production, such as dry matter, sugar content and sugar composition, could directly affect the competitiveness of lactic acid bacteria involved in silage fermentation.

Similar results were obtained in the studies supplemented with organic acid-based silage additives with the current study. For instance, Lindgren et al. (1983) determined that red clover silage decreased the number of lactobacilli and clostridia significantly $(\mathrm{P}<0.05)$. It has been determined that the corn and English grass silages reduced the number of lactobacilli and yeast (Driehuis et al., 2001) and the wheat, maize and sorghum silages reduced the number of lactobacilli, yeast, mold, enterobacteria and clostridia (Filya, 2003). In addition, a formic acid-based preservative added to the corn and sorghum silages was found significantly reduced the number of lactobacilli, yeast, mold, enterobacteria and clostridia (Filya \& Sucu, 2003). It has also been reported that although the additives added to silage do not increase the nutrient quality, they inhibit the growth of microorganisms that cause deterioration, and that the obtained healthy silages can indirectly increase the yield performances of ruminants (Filya, 2001; McDonald et al., 1991).

\section{CONCLUSION}

In conclusion, WV addition did not affect the nutrient content of the silage. Since the high (2\%) concentration of WV had an antimicrobial effect, it adversely affected $\mathrm{pH}$ and lactic acid bacterial community desired for the silage fermentation. The antifungal effect of $\mathrm{WV}$ in parallel with the increased concentration was prominent which indeed thought to accelerate the silage fermentation. However, advanced studies are required on the uses of $\mathrm{WV}$ as a silage additive by using different concentrations and/or different inoculants combined appropriately.

\section{REFERENCES}

Chen, Zheng, Z., Fu, K., Zeng, Z., Wang, J., \& Lu, M. (2015). Torrefaction of biomass stalk and its effect on the yield and quality of pyrolysis products. Fuel, 159, 27-32.

Chen, J. (1994). Effects of enzyme-inoculant systems on preservation and nutritive value of haycrop and corn silages. Journal of Dairy Science, 77(2), 501-12 doi:10.3168/jds.S0022-0302(94)76978-2.

Driehuis, F., Oude Elferink, S., \& Van Wikselaar, P. (2001). Fermentation characteristics and aerobic stability of grass silage inoculated with Lactobacillus buchneri, with or without homofermentative lactic acid bacteria. Grass and Forage Science, 56(4), 33043.

Elferink, S., Driehuis, F., Gottschal, J. C., \& Spoelstra, S. F. (2000). Silage fermentation processes and their manipulation. FAO Plant Production and Protection Papers, 17-30.

Filya, İ. (2001). Silaj teknolojisi. İzmir: Hakan Ofset.

Filya, I. (2003). Organik asitlerin buğday, misır ve sorgum silajlarının mikrobiyal flora ile aerobik stabiliteleri üzerine etkileri. III. Paper presented at the III. Ulusal Zootekni Bilim Kongresi.

Filya, İ., \& Sucu, E. (2003). Silajlarda fermantasyon kalitesi ve aerobik stabilitenin geliştirilmesi üzerinde araştırmalar. Paper presented at the GAP III. Tarım Kongresi.

Garillo, E., Pradhan, R., \& Tobioka, H. (1995). Effects of activated charcoal on growth, ruminal characteristics, blood profiles and feed digestibility in growing sheep. Paper presented at the Proceedings of Faculty of Agriculture Kyushu Tokai University.

Goering, H. K., \& Van Soest, P. J. (1970). Forage fiber analysis. Agricultural handbook no. 379. Virginia, Amerika Birleşik Devletleri: U.S. Agricultural Research Service.

Gül, S., \& Coşkuntuna, L. (2016). Çayır Otu Silajlarına Farklı Katkı Maddesi İlavesinin Silaj Fermantasyonu ve Aerobik Stabilite Üzerine Etkileri.

Jalč, D., Lauková, A., Simonová, M., Váradyová, Z., \& Homolka, P. (2009). The use of bacterial inoculants for grass silage: their effects on nutrient composition and fermentation parameters in grass silages. Czech Journal of Animal Science, 54(2), 8491.

Jatkauskas, J., \& Vrotniakiene, V. (2011). The effects of silage inoculants on the fermentation and aerobic 
stability of legume-grass silage. ŽemdirbystéAgriculture, 98, 367-74.

Jatkauskas, J., Vrotniakiene, V., Ohlsson, C., \& Lund, B. (2013). The effects of three silage inoculants on aerobic stability in grass, clover-grass, lucerne and maize silages. Agriculture and Food Science, 22(1), 137-44.

Ke, W. C., Ding, W. R., Xu, D. M., Ding, L. M., Zhang, P., Li, F. D., et al. (2017). Effects of addition of malic or citric acids on fermentation quality and chemical characteristics of alfalfa silage. Journal of Dairy Science, 100(11), 8958-66.

Kitcherside, M., Glen, E. F., \& Webster, A. J. F. (2000). Fibrecap: an improved method for the rapid analysis of fibre in feeding stuffs. Animal Feed Science and Technology, 86(1-2), 125-32.

Koç, I., Öğün, E., Namlı, A., Mendeş, M., Kutlu, E., \& Yardım, E. N. (2019). The effects of wood vinegar on some soil microorganisms. Applied Ecology and Environmental Research, 17(2), 2437-47.

Koç, I., Yardım, E. N., Çelik, A., Mendeş, M., Mirtagİoğlu, H., \& Namlı, A. (2018). Findık kabuklarından elde edilmiş odun sirkesi'nin in-vitro şartlarında küf etmenlerine karşı antifungal etkisinin belirlenmesi. Bitlis Eren Üniversitesi Fen Bilimleri Dergisi, 7(2), 296-300 doi:10.17798/bitlisfen.425809.

Lee, S. S., Lee, H. J., Paradhipta, D. H. V., Joo, Y. H., Kim, S. B., Kim, D. H., et al. (2019). Temperature and microbial changes of corn silage during aerobic exposure. Asian Australasian Journal of Animal Sciences, 32(7), 988.

Lehmann, J., \& Joseph, S. (2009). Biochar for environmental management. London and New York: Earthscan London.

Lindgren, S., Kaspersson, A., Rydberg, E., Lingvall, P., \& Kartzow, A. D. (1983). Effect of inoculants, grain and formic acid on silage fermentation. Swedish Journal of Agricultural Research (Sweden). 13, 91100.

McDonald, P., Henderson, A., \& Heron, S. (1991). The biochemistry of silage. Marlow, UK: Chalcombe publications.

Namli, A., Akça, M. O., Turgay, E. B., \& Soba, M. R. (2014). Odun sirkesinin tarımsal kullanım potansiyelinin araştırılması. Toprak Su Dergisi, 3(1), 44-52.

Norgate, T., Haque, N., Somerville, M., \& Jahanshahi, S. (2012). Biomass as a source of renewable carbon for iron and steelmaking. ISIJ International, 52(8), $1472-81$.

Pereira, R. C., Muetzel, S., Arbestain, M. C., Bishop, P., Hina, K., \& Hedley, M. (2014). Assessment of the influence of biochar on rumen and silage fermentation: A laboratory-scale experiment. Animal Feed Science and Technology, 196, 22-31.
Rakmai, J. (2009). Chemical determinations, antimicrobial and antioxidant activities of Thai wood vinegars. Prince of Songkla University.

Rui, Z., Wei, D., Zhibin, Y., Chao, Z., \& Xiaojuan, A. (2014). Effects of wood vinegar on the soil microbial characteristics. Journal of Chemical and Pharmaceutical Research, 6(3), 1254-60.

Skaar, I., \& Stenwig, H. (1996). Malt-yeast extractsucrose agar, a suitable medium for enumeration and isolation of fungi from silage. Applied and Environmental Microbiology, 62(10), 3614-9.

Steen, R. W. J., Unsworth, E. F., Gracey, H. I., Kennedy, S. J., Anderson, R., \& Kilpatrick, D. J. (1989). Evaluation studies in the development of a commercial bacterial inoculant as an additive for grass silage: 3. Responses in growing cattle and interaction with protein supplementation. Grass and Forage Science, 44(4), 381-90.

Tiilikkala, K., Fagernäs, L., \& Tiilikkala, J. (2010). History and use of wood pyrolysis liquids as biocide and plant protection product. Open Agriculture, 4, 111-8.

Villalba, J. J., Provenza, F. D., \& Banner, R. E. (2002). Influence of macronutrients and activated charcoal on intake of sagebrush by sheep and goats. Journal of Animal Science, 80(8), 2099-109.

Winters, A. L., Fychan, R., \& Jones, R. (2001). Effect of formic acid and a bacterial inoculant on the amino acid composition of grass silage and on animal performance. Grass and Forage Science, 56(2), 18192.

Woolford, M. K. (1984). The silage fermentation: Marcel Dekker, Inc.

Zellagui, S., Schönnenbeck, C., Zouaoui-Mahzoul, N., Leyssens, G., Authier, O., Thunin, E., et al. (2016). Pyrolysis of coal and woody biomass under N2 and $\mathrm{CO} 2$ atmospheres using a drop tube furnaceexperimental study and kinetic modeling. Fuel, 148, 99-109.

Zhao, G. Q., Ju, Z. L., Chai, J. K., Jiao, T., Jia, Z. F., Casper, D. P., et al. (2018). Effects of silage additives and varieties on fermentation quality, aerobic stability, and nutritive value of oat silage. Journal of Animal Science, 96(8), 3151-60. 